\title{
Thermal and functional properties of starch extracted from tubers cultivated in the Ecuadorian Andean region
}

\author{
Lady QUEZADA-CORREA ${ }^{1 *}$, Oscar CONTRERAS-DIOSES ${ }^{1}$, Omar MARTÍNEZ-MORA ${ }^{1}$, Carlos \\ GÓMEZ-ALDAPA $^{2}$, Esther RAMÍREZ-MORENO², Fabián CUENCA-MAYORGA ${ }^{1}$
}

Received July 02, 2020; accepted March 16, 2021. Delo je prispelo 2. julija 2020, sprejeto 16. marca 2021.

\begin{abstract}
Thermal and functional properties of starch extracted from tubers cultivated in the Ecuadorian Andean region

Abstract: Thermal and functional properties of starch extracted from American taro and Indian shot were determined to assess their use in food products. Starch was extracted by the wet-milling method. Physicochemical composition was determined following the Association of Official Agricultural Chemists (AOAC) protocols. Total fibre was measured by the Total Dietary Fiber Assay Kit. The morphology of starch granules was observed by scanning electronic microscopy (SEM). Gelatinization temperature and viscosity were measured by Differential Scanning Calorimetry (DSC) and with a rapid viscosity analyser (RVA), respectively. Swelling capacity, solubility index, and absorption index were measured at $15,60,70,80$, and 90 ${ }^{\circ} \mathrm{C}$. The yield for Indian shot $(72.5 \%)$ was higher of that for taro $(60.2 \%)$. No significant differences $(p>0.05)$ were found for moisture, ashes, total fibres, and protein; significant differences were found for fat content, total carbohydrates, amylose, and amylopectin. Granules of Indian shot starch featured ovoid shapes (diameter, $30 \mu \mathrm{m}$ ), while granules of American taro starch presented round shapes (diameter, $15 \mu \mathrm{m}$. Gelatinization temperature for American taro $\left(78.33^{\circ} \mathrm{C}\right)$ was higher of that for Indian shot $\left(65.28^{\circ} \mathrm{C}\right)$. Maximum viscosity in Indian shot $(3,535.5 \mathrm{cP})$ was higher of that in American taro $(2,446.5 \mathrm{cP})$. Concerning functional properties, Indian shot starch yielded higher values. Moreover, at high temperature values, American taro starch presented better gelling results than those in Indian shot.
\end{abstract}

Key words: starch; functional properties; Canna edulis (Ker.) Gawl; Xanthosoma sagittifolium (L.) Shott ; thermal properties
Termične in funkcionalne lastnosti škroba pridobljenega iz gomoljnic, gojenih v ekvatorilnih območjih Andov

Izvleček: Termične in funkcionalne lastnosti škroba iz ameriškega tara (karibskega zelja) in užitne kane so bile določene za oceno njihove uporabnosti v prehrambenih izdelkih. Škrob je bil pridobljen $\mathrm{z}$ metodo mokrega mletja. Določitev njegove fizikalno-kemijske sestave je sledila protokolu Zveze kmetijskih kemikov (Association of Official Agricultural Chemists -AOAC). Vsebnost celokupne vlaknine je bila izmerjena s kitom za določanje celokupne prehranske vlaknine. Morfologija škrobnih zrn je bila pregledana z vrstično elektronsko mikroskopijo (SEM). Temperatura želiranja in viskoznost sta bili izmerjeni z metodo diferenčne dinamične kalorimetrije (DSC) in hitrim merilcem viskoznosti (RVA). Sposobnost nabrekanja, indeks topnosti in absorpcijski indeks so bili izmerjeni pri $15,60,70,80$, in $90^{\circ} \mathrm{C}$. Pridelek užitne kane $(72,5 \%)$ je bil večji kot pri ameriškem taru (60,2 \%). Nobene značilne razlike ni bilo $(p>0,05)$ v vsebnosti vode, pepela, celukopne vlaknine in beljakovin; značilne razlike so bile ugotovljene $\mathrm{v}$ vsebnosti maščob, celokupnih ogljikovih hidratov, amiloze in amilopektina. Šrobna zrna užitne kane so bila jajčaste oblike (diameter, $30 \mu \mathrm{m}$ ), med tem, ko so bila pri ameriškem taru okrogla (diameter, $15 \mu \mathrm{m}$ ). Temperatura želiranja je bila pri ameriškem taru višja $\left(78,33^{\circ} \mathrm{C}\right)$ kot pri užitni kani $\left(65,28^{\circ} \mathrm{C}\right)$. Maksimalna viskoznost je bila pri užitni kani večja $(3,535.5 \mathrm{cP})$ kot pri ameriškem taru $(2,446.5 \mathrm{cP})$. Škrob iz užitne kane je imel boljše funkcionalne lastnosti, medtem ko je imel škrob iz ameriškega tara pri višjih temperaturah boljše želirne lastnosti.

Ključne besede: škrob; funkcionalne lastnosti; Canna edulis (Ker.) Gawl.; Xanthosoma sagittifolium (L.) Shott.; termične lastnosti

1 Universidad Técnica de Machala. Av. Panamericana, Km. 5 1/2, vía a Pasaje. Machala, El Oro, Ecuador.

2 Universidad Autónoma del Estado de Hidalgo. Pachuca - Actopan Km. 4.5, Campo de Tiro, 42039 Pachuca de Soto, Hidalgo, Mexico

E-mail of the corresponding author: lmquezada_est@utmachala.edu.ec 


\section{INTRODUCTION}

American taro (Xanthosoma sagittifolium (L.) Shott) and Indian shot (Canna edulis (Ker.) Gawl.) are among the rhizomatous plants cultivated in the Ecuadorian Andean region and used as food sources. Corms of both rhizomes are counted as botanical sources of relevant nutritional value (López et al., 1995). A significant amount of starch, representing circa $68.50 \%$, dry basis, occurs in taro tubers (Palomino et al., 2010), thus representing a practical raw material for a number of uses in food systems and other industrial applications (Torres, et al., 2013). Taro starch is considered as a polymer of high nutritional value, as substantial amounts of dietary fibre occur in its chemical composition (Palomino et al., 2010). Recommendations towards taro starch consumption in human diets have been previously acquainted (Huang et al., 2007). Indian shot rhizomes bestow relevant nutritional values in terms of carbohydrate, protein, and fibre contents, respectively (Barrera et al., 2004). Starch percentage in Indian shot ranges from 75 to $80 \%$ (Gallant et al., 1982). Gelatinization temperatures of starch granules vary accordingly to intrinsic factors, e.g., granule size (bigger granules undergo through swelling processes and retain water), and botanic source of the starch, (García, 2015), amylose/amylopectin ratio (Paredez-López, 1994); extrinsic factors affecting gelatinization temperatures include heating speed, moisture content, mechanical damage over granules, and conditions of starch extraction (Parker y Ring, 2001). Gelatinization effects over a water/starch solution and the influence degree of heating speed over transition processes can be measured by Differential Sweeping Calorimetry (DSC) (Pineda-Gómez et al., 2010). Starch viscosity analysis aids to determine starch uses such as a food component or other applications. Maximum viscosity temperature is higher to that of gelatinization. Maximum viscosity denotes the degree of swelling in starch granules before the breakdown process at certain concentrations (Cortés, 2015). In addition, size and shape variation of starch granules affect gelatinization processes. Size and shape may vary depending on the botanical source from where the starch in question was extracted (Amaya et al., 2011). Due to gelatinization processes, starch granules start to swell, hence affecting the starch solubility. Swelling and releasing of soluble material starts from the hilum to the periphery of the granule (Singh et al., 2003). Scanning Electron Microscopy (SEM) is a technique widely used to observe the size and the shape occurred in starch granules. Concerning starch availability, American taro and Indian shot may replace conventional raw materials commonly used in the food industry such as corn, yam, cassava, potato, etc.
(Vázquez, 2013). The aim of the present research work was to determine thermal and functional properties in starch extracted from American taro (Xanthosoma sagittifolium) and Indian shot (Canna edulis), crops cultivated in the Ecuadorian Andean region, in order to seek for potential uses in processed food products.

\section{MATERIAL AND METHODS}

\subsection{RAW MATERIAL}

For the purposes of the present research work, taro tubers were purchased in Santo Domingo de los Tsáchilas, Ecuador; conditions for growth were the following: rainy season, 625 meters above sea level (MASL), average temperature $21{ }^{\circ} \mathrm{C}$, and $87 \%$ of relative humidity. Indian shot rhizomes were purchased in Loja, Ecuador; conditions for growth were the following: rainy season, 2065 MASL, average temperature $16{ }^{\circ} \mathrm{C}$, and $74 \%$ of relative humidity.

\subsection{STARCH EXTRACTION}

Starch was extracted by the wet-milling method (Bello-Pérez et al, 2010). Weighed, peeled, and chopped rhizomes of both taro and Indian shot were separately embedded in a $5 \%$ citric acid/water solution. Each concoctions were left stand for 40 minutes and afterwards was blended with water (1:5 ratio, concoction : water) at $2000 \mathrm{rpm}$ in a blender (Fleetwood by Skymsem LAR15/25L, Skyfood Equipment LLC., North Miami, FL, United States). The resulted solutions were sieved consecutively through meshes of $0.841,0.149$, and 0.047 $\mathrm{mm}$. Further water washings were carried out over the retained material in the meshes upon any turbid washing liquid was obtained. The filtered liquids were allowed to stand for 4 hours. Sediments containing starch were separated from the liquid phase and were dried at $55^{\circ} \mathrm{C}$ for 24 hours in a laboratory oven (INB 500, Memmert $\mathrm{GmbH}+\mathrm{Co} . \mathrm{KG}$, Schwabach, Germany).

\subsection{STARCH PHYSICOCHEMICAL ANALYSIS}

Percentages of moisture (925.10), ashes (923.03), protein (920.87), and crude fat (920.85), were determined after AOAC methods (AOAC, 2005). Total carbohydrates were determined by subtraction from the total sum of the other physicochemical parameters. Total fibre was determined by the Total Dietary Fiber Assay Kit (Megazyme Ltd., Bray, Ireland). 


\subsection{STARCH GRANULES SIZE AND SHAPE}

Size and shape of starch granules were identified by Scanning Electronic Microscopy (SEM). To improve conductivity and thus to enhance imagining resolution, starch samples were coated with gold. Samples were observed and photographed with a scanning electron microscopy JSM 6300 SEM (SEMTech Solutions, Inc. North Billerica, United States) at X500, X1000, and X1500 zoom values, respectively.

\subsection{STARCH GRANULES SWELLING CAPACITY, SOLUBILITY RATES, AND WATER ABSORP- TION}

$1 \mathrm{~g}$ of each starch sample was weighed in an analytical balance AES 200 (Kern \& Sohn GmbH, Balingen, Germany) and then transferred to centrifuge tubes of 50 $\mathrm{ml}$ volume capacity. $10 \mathrm{ml}$ of deionized water were added to each tube; tubes were agitated in a vortex (WISD VM10) for 30 seconds at room temperature. Afterwards, four centrifuge tubes per each starch sample were heated in a water bath at $60,70,80$, and $90^{\circ} \mathrm{C}$, respectively, for 30 minutes. Then, tubes were cooled in a water bath at $10^{\circ} \mathrm{C}$ and were allowed to stand until reaching room temperature. Cooled tubes were spun at $1200 \mathrm{rpm}$ for 30 minutes in a universal centrifuge Z 326 (Hermle Labortechnik $\mathrm{GmbH}$, Wehingen, Baden-Württemberg, Germany). The resulted supernatant from the centrifugation process on each tube was decanted and weighed in previously-taredand-dried aluminium trays. The resulting gel, wet and dry supernatant were weighed (soluble material mass) in order to determine:

Water absorption index $(W A I)=$ Gel mass $/$ Sample mass

Starch solubility index $(S S I)=($ Soluble material mass $/$ Sample mass) ${ }^{*} 100$

Swelling capacity $(S C)=$ Gel mass/(Sample mass-Soluble material mass)

\subsection{GELATINIZATION TEMPERATURE}

$2 \mathrm{mg}$ (dry basis) of each starch sample were weighed onto previously weighed aluminium sample pans. To prepare a solution containing $20 \%$ of solids, water was added with a micropipette over samples. Calorimetry measurements were determined over sealed sample pans in a DSC Q2000 (TA Instrument, New Castle, United States) at a heating rate of $5{ }^{\circ} \mathrm{C} \mathrm{min}{ }^{-1}$ until $100{ }^{\circ} \mathrm{C}$. An empty sample pan was used as the blank reference to de- velop the baseline. Analyses were carried out threefold. Initial Temperature (Ti), Peak Temperature (Tp), Final temperature (Tf), and Gelatinization Enthalpy $(\Delta \mathrm{H})$ of each sample identified from the generated charts (thermograms).

\subsection{VISCOSITY ANALYSIS}

Viscosity profiles of both starch samples were determined by a Rapid Viscosity Analyzer RVA 4500 (PerkinElmer, Waltham, United States) at the following conditions: profile temperatures from $50{ }^{\circ} \mathrm{C}$ to $92{ }^{\circ} \mathrm{C}$, temperature increment of $5{ }^{\circ} \mathrm{C} \mathrm{min}^{-1}$, stirring rate of 160 $\mathrm{rpm}$. Samples were analysed threefold. According to the equipment specifications, $3 \mathrm{~g}$ of starch were weighed (dry basis) and then $25 \mathrm{ml}$ of water were added. Parameters obtained from RVA graphs were: peak viscosity (PV, maximum viscosity reached by the sample during starch gelatinization), peak time (tP, time required by samples to reach maximum viscosity), peak temperature (TP, time temperature required by samples to reach maximum viscosity), hot paste viscosity (HPV, minimum viscosity to reach $\left.92{ }^{\circ} \mathrm{C}\right)$, cold paste viscosity $(\mathrm{CPV}$, viscosity when the paste cooled down to $\left.50^{\circ} \mathrm{C}\right)$, breakdown (BD, stability of granules after gelatinization), calculated as the difference between PV and HPV, and setback (SB), obtained as the difference between CPV and HPV.

\subsection{STATISTICAL ANALYSIS}

Significant differences $(p \leq 0.05)$ were determined by a multiple comparison test of treatment means (Tukey Post-Hoc test) performed by the statistical package SPSS, version 21 (SPSS Institute Inc., Cary, United States). Graphical representation of data was generated by Origin 50 (Originlab, Northampton, United States).

\section{RESULTS AND DISCUSSION}

\subsection{STARCH PHYSICOCHEMICAL COMPOSITION AND YIELD}

The chemical composition for taro and Indian shot showed similar values to those reported by Palomino et al. (2010) and Quicaña-Avilés (2014), respectively. The chemical composition occurred in starch samples of taro and Indian shot is detailed in Table 1 showed below. Yields obtained were $60.2 \%$ in taro and $72.5 \%$ in Indian shot, respectively on fresh mass basis. 
Table 1: Chemical composition of taro (TS) and Indian shot starches (IS)

\begin{tabular}{lll}
\hline Composition (\%) & TS & IS \\
\hline Moisture & $13.18^{\mathrm{a}} \pm 0.17$ & $16.57^{\mathrm{b}} \pm 0.65$ \\
Ashes & $0.20^{\mathrm{a}} \pm 0.01$ & $0.15^{\mathrm{b}} \pm 0.13$ \\
Protein & $2.05^{\mathrm{a}} \pm 0.01$ & $0.33^{\mathrm{b}} \pm 0.07$ \\
Fat & $0.13^{\mathrm{a}} \pm 0.012$ & $0.11^{\mathrm{a}} \pm 0.02$ \\
Carbohydrates & $84.45^{\mathrm{a}} \pm 0.02$ & $82.85^{\mathrm{b}} \pm 0.83$ \\
Total fibre & $4.11^{\mathrm{a}} \pm 0.03$ & $4.54^{\mathrm{a}} \pm 0.11$ \\
Purity & $93.52^{\mathrm{a}} \pm 0.45$ & $94.88^{\mathrm{b}} \pm 0.37$ \\
Amylose & $35.62^{\mathrm{a}} \pm 1.72$ & $28.59^{\mathrm{b}} \pm 1.05$ \\
Amylopectin & $64.38^{\mathrm{a}} \pm 2.72$ & $71.41^{\mathrm{b}} \pm 1.78$ \\
\hline
\end{tabular}

Average of 3 repetitions $(n=3) \pm$ standard deviation

${ }^{\star}$ Different letters in each row show significant differences $(p<0.05)$

\subsection{STARCH GRANULES SIZE AND SHAPE}

Differences regarding size and shape between taro and Indian shot were found, this was attributed to the different biological and chemical nature on each botanical source. Indian shot starch granules featured homogeneous oval-shaped, smooth surface, and $30 \mu \mathrm{m}$ of size, approximately. Taro starch granules were of circular shape, rough surface, and a size of $15 \mu \mathrm{m}$ on average. Fig. 1 and Fig 2 feature size and shape of granules in both starch samples.

\subsection{GELATINIZATION TEMPERATURE}

Indian shot starch presented a lower peak gelati- nization temperature $\left(65.28^{\circ} \mathrm{C}\right)$ than that in taro starch $\left(78.33^{\circ} \mathrm{C}\right)$. Starch granules with larger diameters gelled in shorter times and lower temperature (García, 2015); howbeit the required enthalpy value for such process was higher in Indian shot starch than that in taro starch: 14.14 and $12.16\left(\mathrm{~J} \mathrm{~g}^{-1}\right)$, respectively. Another salient factor influencing over gelatinization temperature in starch is amylose concentration, i.e., when comparing the gelatinization temperatures between two types of starch of different botanical origin, the one bestowing higher amylose concentration requires higher temperatures in order to reach a gelatinization peak (Paredez-López, 1994). Table 2 depicts gelatinization temperature values in taro starch and Indian shot starch. Fig. 3 shows the gelatinization behaviour of taro starch and Indian shot starch, respectively.
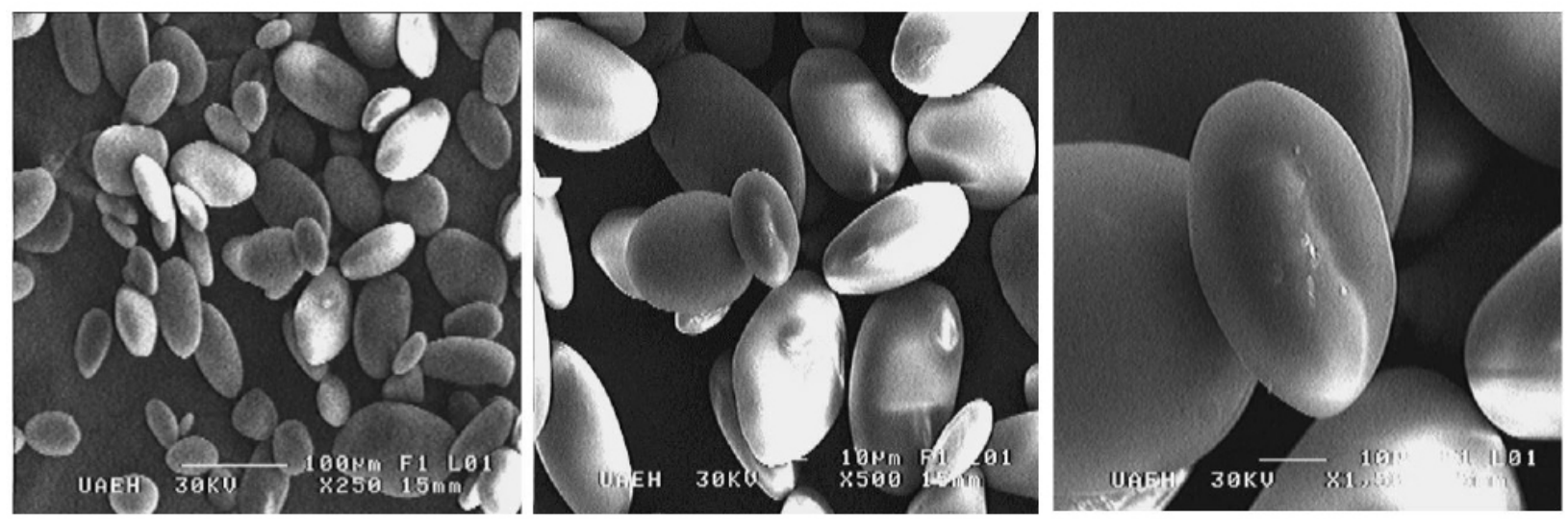

Figure 1: Indian shot starch granules at x 250, x 500, and x 1500, respectively 

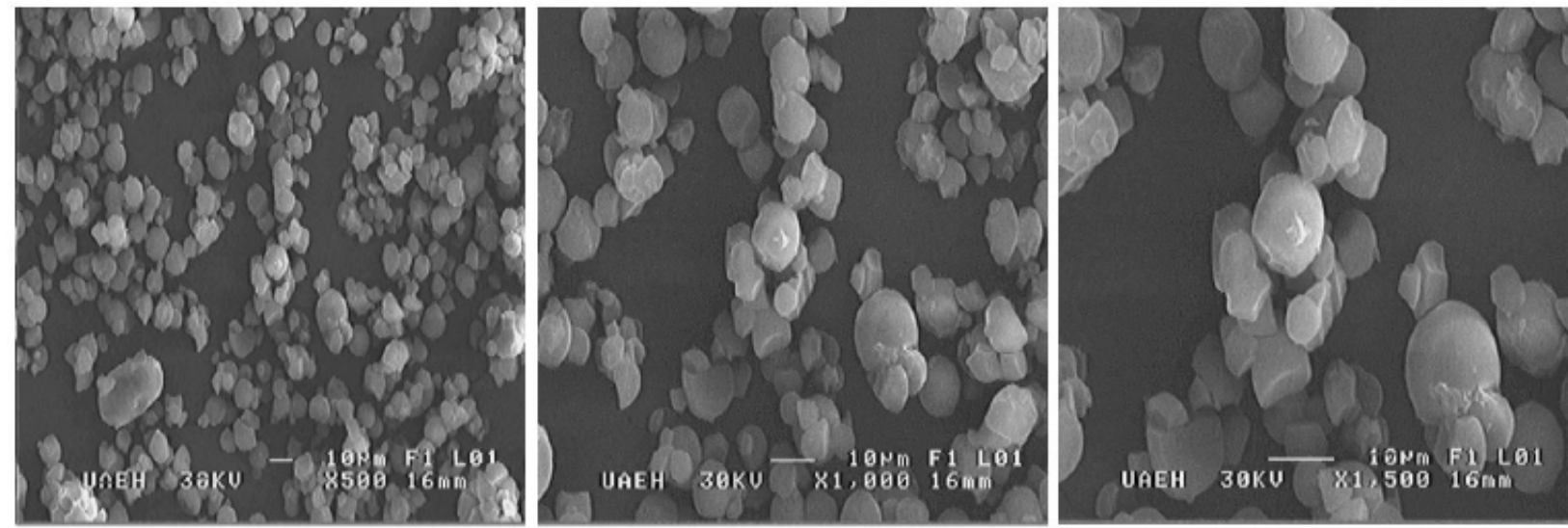

Figure 2: Taro starch granules at x 250, x 500, and x 1500, respectively

Table 2: Gelatinization temperature in taro starch and Indian shot starch

\begin{tabular}{lllll}
\hline Sample & $\mathrm{Ti}\left({ }^{\circ} \mathrm{C}\right)$ & $\mathrm{PGT}\left({ }^{\circ} \mathrm{C}\right)$ & $\mathrm{Tf}\left({ }^{\circ} \mathrm{C}\right)$ & $\Delta \mathrm{H}(\mathrm{J} / \mathrm{g})$ \\
\hline TS & $76.09^{\mathrm{a}} \pm 0.21$ & $78.33^{\mathrm{a}} \pm 0.12$ & $84.72^{\mathrm{a}} \pm 0,03$ & $12.16^{\mathrm{a}} \pm 0,31$ \\
IS & $62.48^{\mathrm{b}} \pm 0.05$ & $65.28^{\mathrm{b}} \pm 0.07$ & $73.12^{\mathrm{b}} \pm 0.18$ & $14.14^{\mathrm{b}} \pm 0,04$ \\
\hline
\end{tabular}

Ti: initial temperature, PGT: peak gelatinization temperature, Tf: final temperature, $\Delta \mathrm{H}$ : gelatinization enthalpy. Average of 3 repetitions $(n=3) \pm$ standard deviation

${ }^{\star}$ Different letters in each row show significant differences $(p<0.05)$

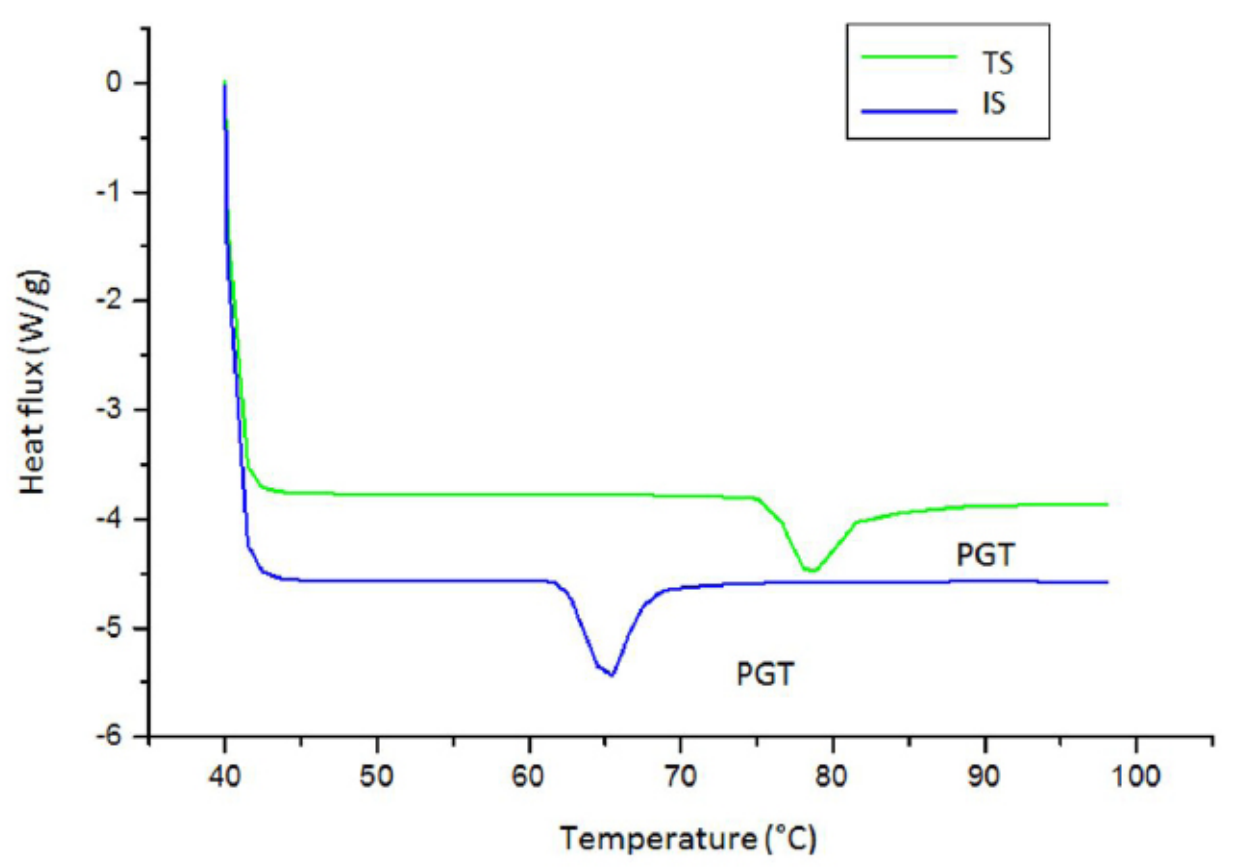

Figure 3: Gelatinization behaviour of taro and Indian shot starches 
Hernández-Medina et al. (2008), reported gelatinization temperatures for starch extracted from Makal (Xanthosoma yucatanensis Engl.) and Sago (Cycas circinalis L.) of $78.4{ }^{\circ} \mathrm{C}$ and $74.9{ }^{\circ} \mathrm{C}$, respectively. Gelatinization temperatures found in taro starch were consistent to the previously reported. Indian shot starch showed a gelatinization temperature values similar to those reported for starch extracted from sweet potato, cassava, oat, and barley $\left(61.3,65.2,66.5\right.$, and $67.3{ }^{\circ} \mathrm{C}$, respectively) (Cantellano-Jarrillo et al., 2016). Starch featuring high gelatinization temperatures may be used in food products requiring high processing temperatures, e.g., canned. Starch featuring lower gelatinization temperatures may be incorporated into formulations of products such as sweets, puddings, and soups (Hernández-Medina et al., 2008).

\subsection{RAPID VISCOSITY ANALYSIS (RVA)}

As depicted in Fig. 4, starch extracted from Indi- an shot showed a higher peak viscosity in shorter time and a lower heating temperature $(3535.5 \mathrm{cP} ; 3.4 \mathrm{~min}$ at $\left.76.45^{\circ} \mathrm{C}\right)$ compared to starch extracted from taro $(2446.5$ $\mathrm{cP} ; 4.56 \mathrm{~min}$ at $89.4^{\circ} \mathrm{C}$ ). This difference is related to the size of starch granules. Starch extracted from Indian shot presented granules with a larger average size than those occurred in starch extracted from taro. Accordingly, the former absorbs larger quantities of water than the latter. Fig. 4 shows the viscosity amylograms found for starch extracted from taro and Indian shot, respectively.

Gel generated from taro starch showed a lesser degree of instability, i.e., breakdown, than that of the gel obtained from Indian shot starch. The evaluation of the breakdown provides information regarding gel stability and resistance when starch is subjected to shear in further food processing. The lower the value, the more stable the starches are opposite to mechanical fragmentation (Lucas, et al., 2013). Table 3 presents the results for RVA over starch extracted from taro and Indian shot, respectively.

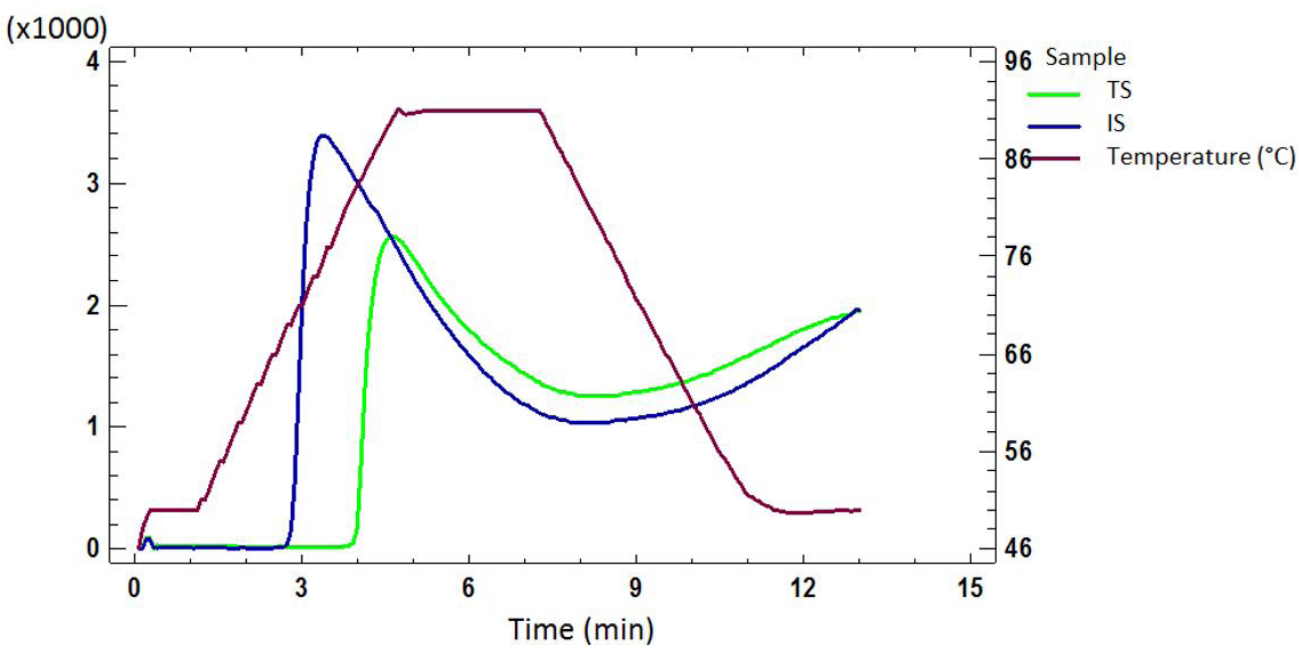

Figure 4: Viscosity amylograms for taro and Indian shot starches

Table 3: RVA results for starch extracted from taro (TS) and Indian shot (IS)

\begin{tabular}{lll}
\hline Parameters & TS & IS \\
\hline Peak viscosity $(c P)$ & $2,446.50^{\mathrm{a}} \pm 113.34$ & $3,535.50^{\mathrm{b}} \pm 197.28$ \\
Viscosity peak time $(\mathrm{min})$ & $4.56^{\mathrm{a}} \pm 0.12$ & $3.40^{\mathrm{b}} \pm 0.02$ \\
Viscosity peak temperature $\left({ }^{\circ} \mathrm{C}\right)$ & $89.40^{\mathrm{a}} \pm 0.56$ & $76.45^{\mathrm{b}} \pm 0.07$ \\
Hot paste viscosity $(\mathrm{cP})$ & $1,315.00^{\mathrm{a}} \pm 69.29$ & $1,176.00^{\mathrm{b}} \pm 80.61$ \\
Cold paste viscosity $(\mathrm{cP})$ & $1,845^{\mathrm{a}} \pm 104$ & $2,021.00^{\mathrm{b}} \pm 97.58$ \\
Breadkdown $(\mathrm{cP})$ & $1,131.50^{\mathrm{a}} \pm 32.63$ & $2,359.50^{\mathrm{b}} \pm 86.67$ \\
Setback $(\mathrm{cP})$ & $530.00^{\mathrm{a}} \pm 29.30$ & $845.00^{\mathrm{b}} \pm 58.19$ \\
\hline
\end{tabular}


Starch extracted from Indian shot showed a greater capacity for setback and retrogradation than the starch extracted from taro. The setback in soluble polymers of starch and insoluble granular fragments during the cooling phase is associated with retrogradation (Álzate et al., 2013). Starch samples studied in this research presented higher maximum viscosity values than those in starch samples extracted from other tubers, such as cassava $(1,116 \mathrm{cP})$, and two malanga varieties (Colocasia esculenta (L.) Schott; 1,170 cP and 975 cP) (Escobar et al., 2009 and Torres et al., 2013).

\subsection{STARCH GRANULES SWELLING CAPACITY, SOLUBILITY RATES, AND WATER ABSORP- TION}

As the temperature of a starch solution rose above $30{ }^{\circ} \mathrm{C}$, rates of solubility, water absorption, and swelling capacity increased, this due to the interaction between water hydrogen bonds and starch glycosidic bonds, therefore resulting in gelatinization of starch. Due to higher amylopectin contents, indices were higher for starch extracted from Indian shot than those for starch extracted from taro. Amylopectin enhances the acquainted properties; in the other hand, amylose is an inhibitor of those (Paredez-López, 1994). Figs, 5, 6, and 7 depict swelling capacity, solubility index, and water absorption index for starch extracted from taro and Indian shot, respectively.

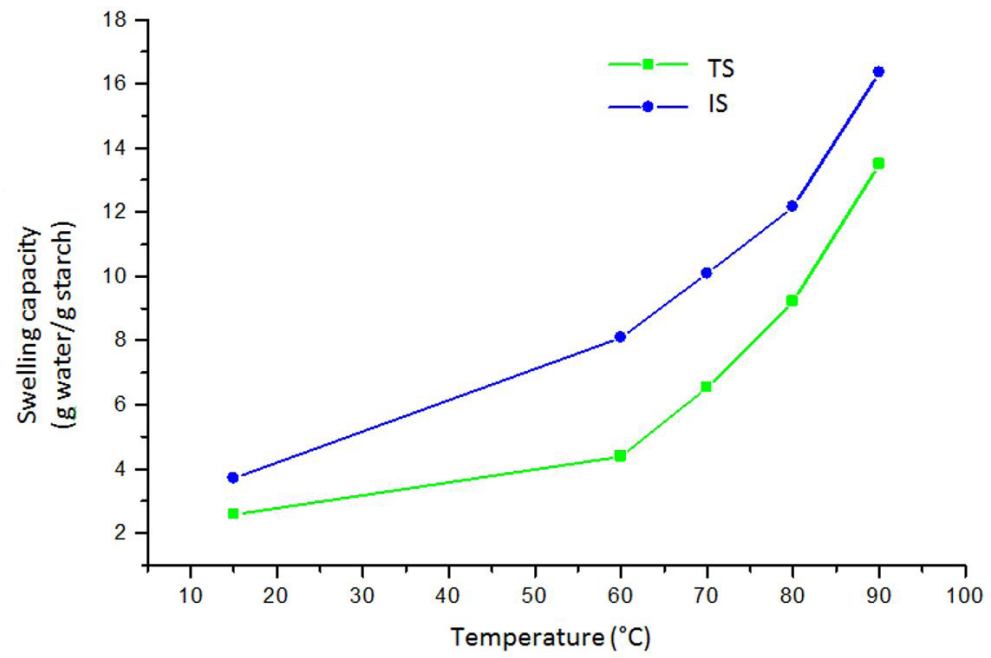

Figure 5: Swelling capacity for taro and Indian shot starches

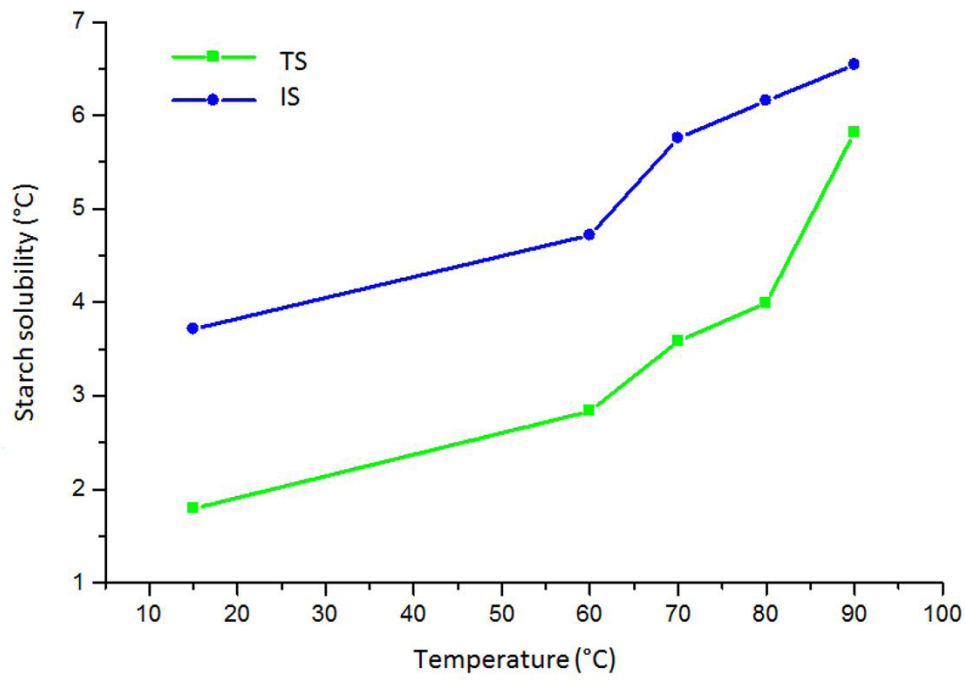

Figure 6: Solubility index for taro and Indian shot starches 


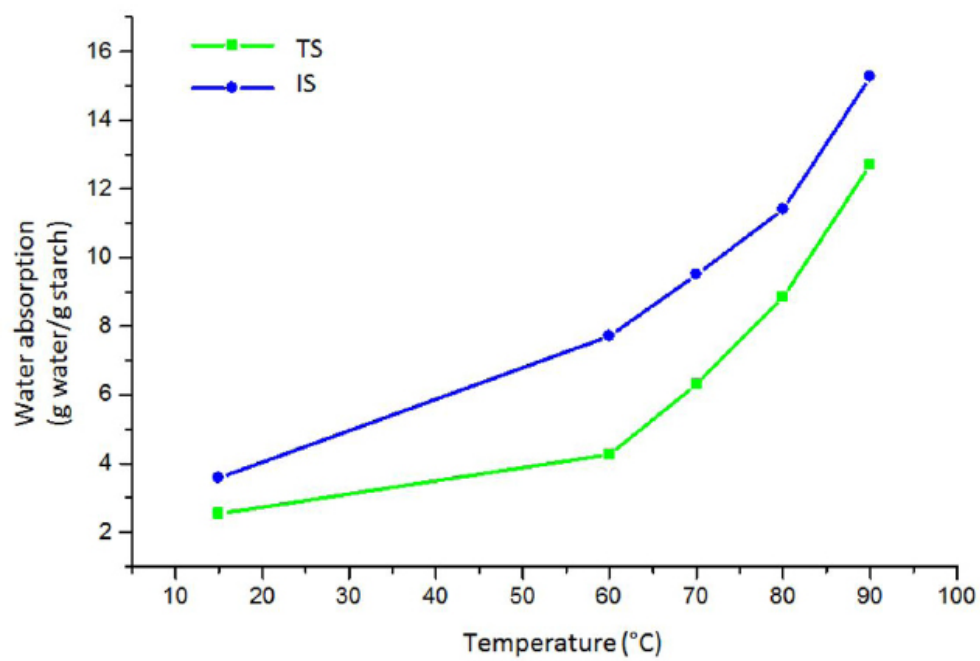

Figure 7: Water absorption index for taro and Indian shot starches

A positive inflection in the slope obtained for these indices can be observed from $70{ }^{\circ} \mathrm{C}$ in starch extracted from taro; in starch extracted from Indian shot, the inflection is less pronounced; this is related to the viscosity peak temperature. At $90{ }^{\circ} \mathrm{C}$, the swelling capacity was 13.49 and $16.53 \mathrm{~g}$ water/g starch for taro and Indian shot, respectively. Regarding water absorption, values found were 12.70 and $15.27 \mathrm{~g}$ water/g starch for Indian shot and taro, respectively. The values of the solubility index values for the studied starches were $3.99 \%$ for taro and $4.54 \%$ for Indian shot. These results were similar to those previously reported, as well as for swelling capacity. Alvira-Maníos et al. (2015) and Fonseca et al. (2016) declared 13.69 and $15.23 \mathrm{~g}$ water/g starch for taro and Indian shot, respectively. Low values for swelling capacity are related to low peak viscosity in starch and a lower degree in the rupture in granules (García, 2015); this was observed in taro starch. In the other hand, starch granules with higher swelling capacity usually have higher peak viscosity values, behaviour observed for Indian shot starch, as reported by Ktenioudaki et al. (2013).

\section{CONCLUSIONS}

American taro and Indian shot rhizomes denote high yields for starch extraction and may be considered as a sound alternative to obtain this biopolymer. Starch granules with larger diameters and higher water absorption capacity reached maximum viscosity values in shorter periods and at lower temperatures, phenomenon observed in Indian shot starch. Taro starch featured higher amylose contents than that in Indian shot starch, higher peak gelatinization temperature was observed in the former. However, due to a smaller average granule size, lower values for gelatinization enthalpy, swelling capacity, absorption, and solubility were found. According to the results found for thermal and functional properties in starch samples extracted from Indian shot and American taro, promising results may occur when adding these types of starch as an alternative matrix or input in food processing, especially when the process demands of high temperatures and where starch has been used as an essential ingredient, such as some types of canned foods (e.g. ready-made soups), ready-made food for infants, and acting as a wall material in the use of encapsulated active principles dedicated to release flavours and colours in food products, to name a few.

\section{REFERENCES}

Alvira-Maníos, L. F., Chávez-Jaurégui, R. N., and Bosques-Vega, A. (2015). Caracterización del almidón del cormo de la yautía (Xanthosoma spp.) del cultivar nazareno. Conference Article: Acta de la Sociedad Puertorriqueña de Ciencias Agrícolas (SOPCA), Coamo, Puerto Rico.

Álzate, E., Quintero, V., and Lucas, J. (2013). Determinación de las propiedades térmicas y composicionales de la harina y almidón de chachafruto (Erytina edulis Triana Ex Micheli). Temas Agrarios, 21-35. https://doi.org/10.21897/rta. v18i2.714

Amaya, C., Osorio, F., Agama, E., Yee, H., and Bello, L. (2011). Physicochemical and digestibility properties of doublemodified banana (Musa paradisiaca L.) starches. Agricultural and Food Chemistry Journal, 59, 1376-1382. https:// doi.org/10.1021/jf1035004

Barrera, V., Tapia, C., Monteros, A. (2004). Raíces y tubérculos andinos: alternativas para la conservación y uso sostenible en el Ecuador. Quito, Ecuador: Instituto Nacional Autónomo 
de Investigaciones Agropecuarias (INIAP). http://repositorio.iniap.gob.ec/handle/41000/3261

Bello-Pérez, L.A., Sánchez-Rivera, M.M., Núñez-Santiago, C., Rodríguez-Ambriz, S.L., and Román-Gutiérrez, A.D. (2010). Effect of the pearled in the isolation and the morphological, physicochemical and rheological characteristics of barley starch. Carbohydrate Polymers, 81(1), 63-69. https://doi.org/10.1016/j.carbpol.2010.01.056

Cantellano-Jarrillo, G., Rodríguez-Marín, M. L., Román-Gutiérrez, A.D., and Guzmán-Ortiz, F.A. (2016). Evaluación de las propiedades fisicoquímicas de almidones de diferentes cereales. Pädi Boletín Científico De Ciencias Básicas E Ingenierías Del ICBI, 3(6). https://doi.org/10.29057/icbi. v3i6.573

Cortés, E. (2015). Caracterización de almidones de ñame (Dioscorea alata), ñampi (Colocasia esculenta), tiquisque (Xanthosma saggitifolium) y evaluación de su uso potencial como materia prima para la producción de una pasta alimenticia a base de harina de arroz. (Bachellor dissertation), Universidad de Costa Rica, San José. http://repositorio.sibdi.ucr.ac.cr:8080/jspui/handle/123456789/3413

Escobar, A., Dufour, E., Sánchez, T., Giraldo, A., and Dufour, D. (2010). Evaluación de yuca (Manihot esculenta Crantz) de altura para la producción de almidón de yuca. Conference article: Centro Internacional de Agricultura Tropical (CIAT). Retrieved on April 19, 2019 from: http://www.slideshare.net/CIAT/evaluacin-de-yuca-manhiot-esculenta-crantz-de-altura-para-la

Fonseca, H., Méndez, G., Velázquez, G., and Gómez, C. (2016). Thermal study in the interactions of starches blends: Amaranth and achira. Food Hydrocolloids, 640-648. https://doi. org/10.1016/j.foodhyd.2016.06.027

Gallant, D., Bewa, H., Buy, Q., Bouchet, B., Szylit, O., and Sealy, L. (1982). On ultrastructural and nutritional aspects of some tropical tuber starches. Starch/Stärke, 255-262.

García, A. (2015). Obtención de un polímero biodegradable a partir de almidón de maíz. Retrieved on April 04, 2019 from: https://www.itca.edu.sv/wp-content/themes/elaniinitca/docs/2015-Obtencion-de-un-polimero-biodegradable. pdf

Hernández-Medina, M., Torruco-Uco, J.G., Chel-Guerrero, L., and Betancur-Ancona, D. (2008). Caracterización fisicoquímica de almidones de tubérculos cultivados en Yucatán, México. Food Science and Technology, 28(3), 718-726. http://dx.doi.org/10.1590/S0101-20612008000300031

Huang, C., Chen, W., and Wang, C. (2007). Comparison of Taiwan paddy and upland-cultivated taro (Colocasia esculenta
L.) cultivars for nutritive values. Food Chemistry, 250-256. https://doi.org/10.1016/j.foodchem.2006.04.044

Ktenioudaki, A., O'Shea, N., and Gallagher, E. (2013). Rheological properties of wheat dough supplemented with functional by products of food processing: Brewer's spent grain and apple pomace. Journal of Food Engineering, 362-368. https://doi.org/10.1016/j.jfoodeng.2012.12.005

López, M., Vásquez, M., López, R. (1995). Raíces y tubérculos. La Habana: Pueblo y Educación.

Lucas, J., Quintero, C., and Cárdenas, V. (2013). Caracterización de harina y almidón obtenidos a partir de plátano guineo AAAea (Musa sapientum L.). Acta Agronómica, 83-96.

Palomino, C., Molina, Y., and Peréz, E. (2010). Physical and chemical characterization of flour and starches of tubers of Colocasia esculenta (L.) Schott and Xanthosoma sagittifolium (L.) Schott. Revista de la Facultad de Agronomía, 58-66.

Paredez-López, O. (1994). Amaranth Biology, Chemistry, and Technology. CRC. Press. Irapuato, 107-124.

Parker, R., and Ring, S. (2001). Aspect of the physical chemistry of starch. Journal of Cereal Science, 1-17. https://doi. org/10.1006/jcrs.2000.0402

Pineda-Gómez, P., Coral, D., Arciniegas, M., Rorales-Rivera, A., and Rodríguez-García, M. (2010). Papel del agua en la gelatinización del almidón de maíz: estudio por calorimetría diferencial de barrido. Ingeniería y Ciencia, 129-141. http://www.scielo.org.co/pdf/ince/v6n11/v6n11a08.pdf

Quicaña-Avilés, Z.L. (2014). Extracción y caracterización del almidón de achira (Canna edulis). (Bachellor thesis) Universidad Nacional de San Cristóbal de Huamanga, Huamanga. http://repositorio.unsch.edu.pe/handle/UNSCH/2269

Singh, N., Singh, J., Kaur, L., Singh-Sodhi, N., and SinghGill, B. (2003). Morphological, thermal and rheological properties of starches from different botanical sources. Food Chemistry, 219-231. https://doi.org/10.1016/S03088146(02)00416-8

Torres, A., Montero, P., and Durán, M. (2013). Propiedades fisicoquímicas, morfológicas y funcionales del almidón de malanga (Colocasia esculenta). Revista Lasallista de Investigación, 52-61. https://www.redalyc.org/ pdf/695/69529816007.pdf

Vázquez, L. L. (2013). Evaluación de mezclas de harina de malanga y maíz para elaborar tortillas. Tabasco, México: Consejo Nacional de Ciencia y Tecnología. https:// 1library.co/document/lq5wjojq-evaluacion-de-mezclas-de-harina-de-malanga-y-maiz-para-elaborar-tortillas. html?tab=pdf 